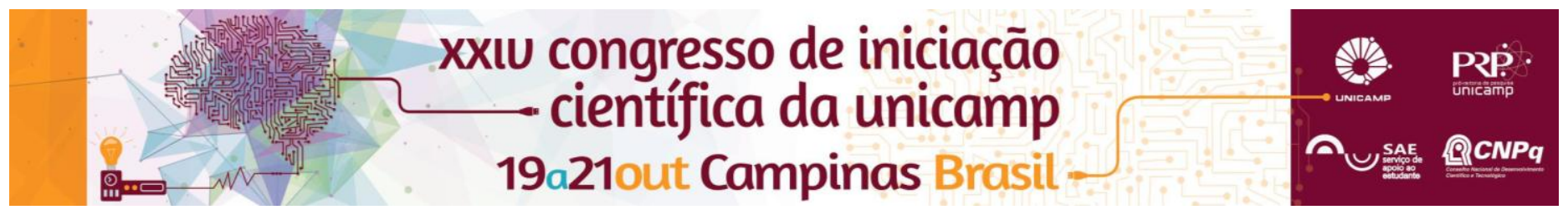

\title{
A transformação do esgoto em água de reúso, adubo e energia
}

\author{
Andresa R. Pereira Ferreira, Bianca M. Gomes da Silva, Jonatan R. Checatto, Adriano L. Tonetti.
}

\section{Resumo}

O filtro de areia e o reator anaeróbio são alternativas para tratamento do esgoto. O efluente por eles gerados podem ser aproveitados na agricultura pois são ricos em nutrientes. O presente estudo compara a eficiência desses efluentes como adubos em cultivo de alface utilizando parâmetros como número de folhas, altura, peso das folhas e raízes.

\section{Palavras-chave:}

Efluente tratado, cultivo de alfaces, fertilizantes alternativos.

\section{Introdução}

O esgoto doméstico é considerado uma alternativa de fertilizante para a agricultura, visto que possui importantes nutrientes, como o nitrogênio, que auxilia o crescimento vegetal ${ }^{1}$. Por isso, a utilização desses efluentes nas lavouras está crescendo consideravelmente nos últimos anos. Porém, existem limitações ao seu uso devido à presença de patógenos, podendo causar impactos no solo e contaminar os alimentos. O objetivo deste estudo foi comparar a eficiência da utilização do esgoto tratado em filtro anaeróbio e de areia como fertilizante agrícola. Dessa forma, verificar a viabilidade do uso desses efluentes nas atividades agrícolas. Neste experimento utilizaram-se cinco vasos com mesma quantidade de solo para cada tipo de tratamento: (1) solo natural utilizando apenas água como irrigação (controle), (2) adição de NPK ao solo e irrigação com água (controle), (3) solo natural irrigado com efluente do filtro anaeróbio e (4) solo natural e irrigação com efluente do filtro de areia. Para o experimento a Alface Lisa Liz (Lactuca sativa) foi escolhida como o vegetal a ser fertilizado.

\section{Materiais e Métodos}

O experimento foi realizado no Laboratório de Protótipos de Tratamento de Águas e Efluentes (LabPro) na Unicamp, com duração de 40 dias. Foram medidas a temperatura $\left({ }^{\circ} \mathrm{C}\right)$ e umidade $(\%)$ do ar diariamente.

Peneirou-se o solo em malha 2 e a massa de solo adicionada em cada vaso foi padronizada. Após estes procedimentos, cada vaso foi regado com água (para o controle e o NPK) e com esgoto tratado (para o filtro anaeróbio e o filtro de areia) todos os dias úteis. Foram medidos, os seguintes parâmetros: o peso inicial e final de cada vaso, a quantidade de folhas existentes em cada muda de alface e a altura de cada uma delas. E todos esses dados eram anotados em tabelas detalhadas para controle geral do experimento.

\section{Resultados e Discussão}

A Figura 1 apresenta a altura média das alfaces em função do número de dias. Foi observado que no $19^{\circ}$ dia de experimento o cultivo irrigado com efluente tratado pelo filtro de areia obteve os melhores desenvolvimentos.

O número de folhas, o peso fresco da raiz e das folhas após 40 dias são apresentados na Figura 2. O peso fresco de raiz do fertilizante NPK e do efluente do Filtro de Areia obtiveram os resultados mais expressivos.
Figura 1. Evolução da altura das alfaces.

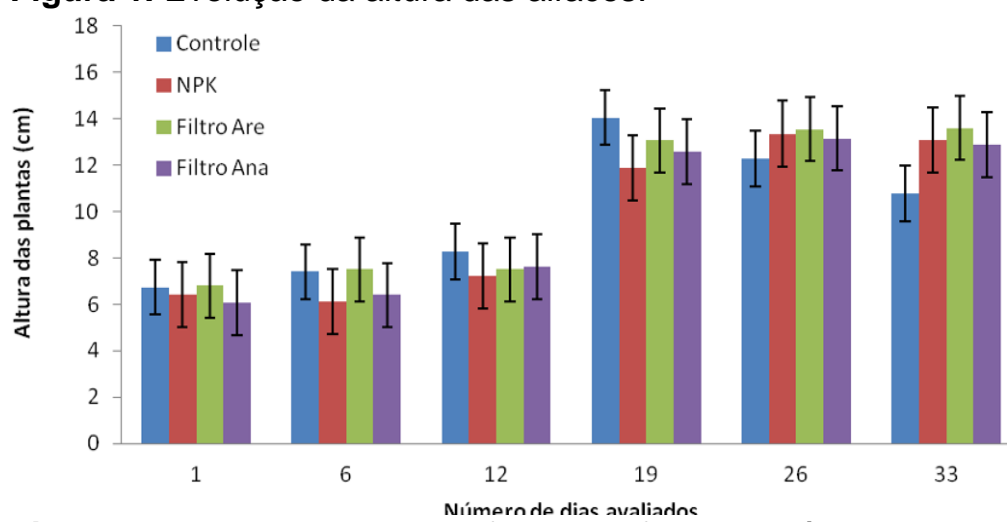

Figura 2. Produção de massa fresca de folhas e raízes e número total de folhas da alface submetida a diferentes fontes de nutrientes.

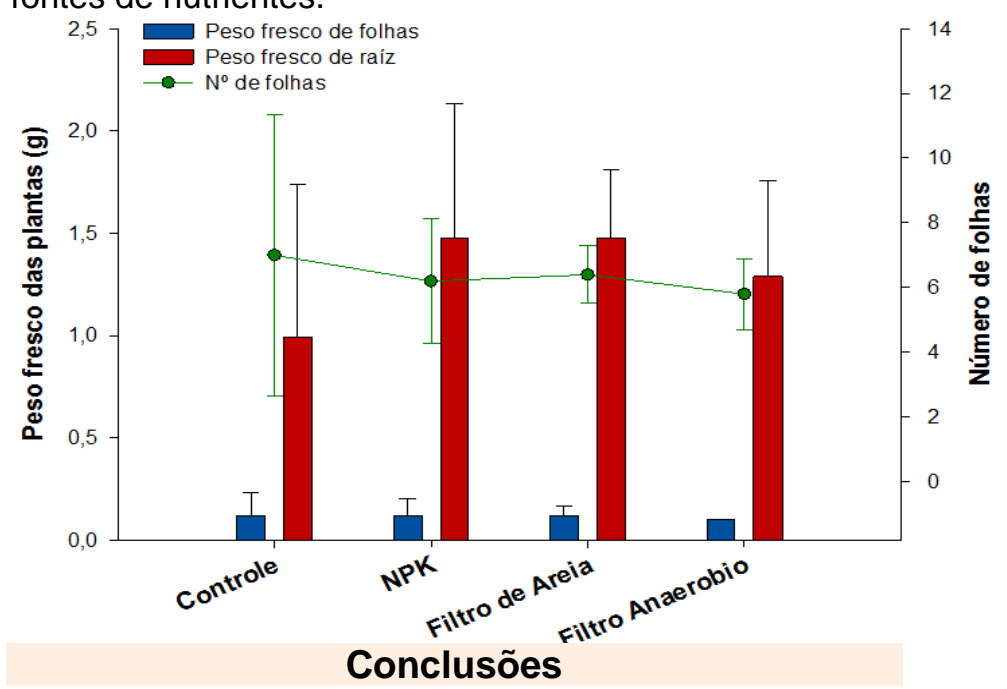

Com base nos dados obtidos, conclui-se que o esgoto tratado possui capacidade para atuação como fertilizante, logo apresentando vantagens para sua aplicação na agricultura. Entretanto, é importante ressaltar que seu excesso poderá levar a efeitos não desejados.

\section{Agradecimentos}

Os autores agradecem ao CNPq pelo auxílio, ao orientador Adriano Luiz Tonetti e aos monitores pelo tempo dedicado.

${ }^{1}$ BERTONCINI, Edna Ivani. Tratamento de efluentes e reuso da água no meio agrícola. Revista Tecnologia \& Inovação Agropecuária, v. 1, n. 1, p. 152-169, 2008. APA 